\section{NEW RECORD OF CONCHOSTRACA (CRUSTACEA) FROM PUNE, MAHARASHTRA}

\author{
H.V. Ghate ${ }^{1}$, N. Rane ${ }^{1}$ and S.G. Patil ${ }^{2}$ \\ ${ }^{1}$ Department of Zoology, Modern College, Pune, Maharashtra \\ 411005, India. \\ ${ }^{2}$ Western Regional Station, Zoological Survey of India, Vidyanagar, \\ Sector 29, Pune, Maharashtra 411044, India. \\ Email: hemantghate@hotmail.com
}

During a survey of local waterbodies of Pune and nearby areas, some specimens of the order Conchostraca were collected, in August 1999, from a temporary rainwater pool on Alandi Road, Pune (Maharashtra State). There is no lake nearby but a river flows about $5 \mathrm{~km}$ away from the spot. Examination of this material revealed existence of three species, out of which two species are new records for this region. Ghate and Patil (1995) have already recorded the species Leptestheriella maduraensis from Pune. Perusal of literature showed that there is no record of the other two species from Pune District and even from Maharashtra State.

There are a few reports of Conchostraca from different parts of India: such as the works of Baird (1859), Tiwari (1962, 1965, 1966), Nayar and Nair (1968), Nayar (1965), Joseph et al. (1992) and Royan and Alfred (1971).

Class: Crustacea

Sub Class: Branchiopoda

Order: Conchostraca

\section{Eulimnadia michaeli Nayar \& Nair}

Material examined: Four females.

Distribution: Madurai, Tamil Nadu (Nayar \& Nair, 1968) and Maharashtra (present record).

Remarks: Resembles Eulimnadia inflecta Mattox in shape of the shell, nature of telson, dorsal spines and position of the forked filament on the telson. But E. inflecta can be easily distinguished by its characteristic, strongly concave, and much inflated nature of the front of the head.
Material examined: Two females.

Distribution: Madurai, Tamil Nadu (Nayar \& Nair, 1968), Andhra Pradesh (Joseph et al., 1992), and Kirkee-Pune and Alandi Road, Pune, Maharashtra (Ghate \& Patil, 1995 and present record).

Remarks: Resembles L. gigas and L. inermis in few characters but differs in nature of shell and rostrum. The present form is having spines and setae on dorsal armature of body segment.

\section{Leptestheriajaisalmerensis Tiwari (1962)}

Material examined: Two females.

Distribution: Rajasthan (Tiwari, 1962), Maharashtra (present record).

Remarks: L. jaisalmerensis is unique in sculpturing of the shell and structure of the head.

\section{Acknowledgements}

Authors are grateful to the authorities of Modern College, Pune; Director, Zoological Survey of India, Kolkata, and Officer-InCharge, WRS, ZSI, Pune, for permission to carry out this work.

\section{References}

Baird, W. (1859). Description of some new recent Entomostraca from Nagpur collected by Rev. S. Hislop. Proceedings of the Zoological Society, London LXIII: 231-234.

Ghate, H.V. and S.G. Patil (1995). New record of a conchostracan (Crustacea: Branchiopoda) from Maharashtra State. Journal of the Bombay Natural History Society 92: 128.

Joseph, A.N., T. Ramakrishna and S.G. Patil (1992). On a new record of Conchostraca (Crustacea) from Andhra Pradesh. Records of Zoological Survey of India 90(1-4): 305-306.

Nayar, C.K.G. (1965). Three new species of Conchostraca (Crustacea: Branchiopoda) from Rajasthan. Bulletin of Systematic Zoology 1(1): 19-24.

Nayar, C.K.G. and K.K.N. Nair. (1968). On the collection of Conchostraca (Crustacea: Branchiopoda) from South India, with the description of two new species Hydrobiologia 32: 219-224.

Royan, J.P. and J.R.B. Alfred (1971). Lynceus serratus sp.nov. (Conchostraca: Lynceidae) from southern India. Crustceana 21: 37-40.

Tiwari, K.K. (1962). New species of Conchostraca. Proceedings of the First All India Congress: Zoology 1959, Part 2: 180-190.

Tiwari, K.K. (1965). New species of Leptestheria Sars (Crustacea: Conchostraca) from India. Zoologischer Anzeiger 174(3): 209-214

Tiwari, K.K. (1966). A new genus and species of clam shrimp (Crustacea: Branchiopoda: Conchostraca) from the Sambhar Lake, Rajasthan. Proceedings of Zoological Society, Calcutta 19:67-76 